\title{
BACKGROUND CHARACTERISTICS OF THE INDIVIDUALS ATTAINING HIGHER EDUCATION IN INDIA: A SOCIOLOGICAL STUDY OF SRINAGAR CITY
}

\author{
RABIYA YASEEN BAZAZ \\ Department of Sociology, Aligarh Muslim University, \\ Aligarh Pin 202002, India \\ E-mail address: rabiyabazaz@gmail.com \\ ORCID: https://orcid.org/0000-0002-2954-4728 \\ MOHAMMAD AKRAM \\ Department of Sociology, Aligarh Muslim University, \\ Aligarh Pin 202002,India \\ E-mail address: akram_soc@yaho.co.in \\ ORCID: https://orcid.org/0000-0002-4874-6149
}

\begin{abstract}
Aim. Higher education has experienced major changes in the last few decades in India in terms of its expansion, content, and reach. The massification of higher education has increased access to education and people belonging to different social backgrounds are getting enrolled in higher education. A pertinent question that emerges here is what kind of relationship exists between the background characteristics of people and the levels and types of higher education they attain. This descriptive study provides a comprehensive answer.

Method. This empirical work was conducted in Srinagar city of India. It covered 704 respondents from 245 households. The survey method was used for collecting primary data and structured interviews were conducted, making use of the interview-schedule.

Results. This study finds that higher education in Srinagar is readily available for many but such availability is embedded within constraints related to gender, age, occupation, and education of parents and caste-related identities. People coming from different social backgrounds acquire different types and levels of higher education. It creates a hierarchy among and within academic courses of higher education and inequalities among the groups.

Conclusion. Higher education reflects as well as promotes social inequalities in a contemporary context and thus the egalitarian goals of higher education are becoming compromised. There is a need to bring a change in the courses and contents of higher education so that it can address the dynamic needs of people coming from different
\end{abstract}


backgrounds. Education needs to become a vehicle for liberation and social transformation and should not remain a mere agency of social reproduction.

Key words: social background, higher education courses, higher education in different contexts, gender, caste, parent's background, descriptive study

\section{INTRODUCTION}

$\mathrm{E}$ ducation provided in post-secondary and tertiary institutions is generally categorised as higher education. Theocharis Kromydas (2017) defines higher education as a stage in which teaching and research can be accommodated in an organised fashion for the promotion of various types of knowledge, applied and theoretical. Gordon Graham (2013) dinstinguishes three kinds of institutions related to higher education namely: university-college, research-university, and technical university. While tracing their historical origins, he states that university colleges largely focus on providing moral, traditional, and religious values. Advancement of scientific knowledge gives rise to research institutions, which focus on producing and spreading scientific knowledge. The industrial revolution gave rise to a technical university, whose aim was to provide formal industrial skills. Today, the higher education system has become very complex with a variety of institutions and universities worldwide following a hybrid approach where all traditions collaborate with each other and provide professional, technical, vocational, and other standard or traditional courses.

Higher education from the past few decades has experienced a remarkable transformation in terms of its expansion and purpose. Albert Henry Hasley (2006) argues that higher education has multiple ends; however, in the contemporary world, the role of higher education is frequently associated with the formation of human capital. It is also argued that one of the important roles of education is enhancing capability (Saito, 2003; Walker \& Unterhalter, 2007). The capability approach questions the human capital theory, which sees education as an ordinary investment, and the structuralist and post-structuralist approaches of education support the supremacy of institutional structures and power over the individual (Sen, 1971, 1985, 1993, 2000). Going beyond human capital, higher education also helps in the formation of social and cultural capital (Bourdieu \& Passeron, 1977; Bourdieu, 1996; Coleman, 1988). Besides inculcating particular instrumental and market skills higher education also helps in developing moral values, insight, talent, and critical thinking among individuals. Kromydas (2017) rightly stated that higher education is the place where money and moral values compete and collaborate simultaneously.

The post-second world war era has been characterised by the massification of higher education. Before this, higher education was confined to selected few (Gumport, 2007). There are many political, social, cultural, and economic factors responsible for the massification (Kariwo, Gounko, \& Nungu, 2014). Although global processes result in the massification of higher education, such massification has also intensified the structural and cultural inequalities 
within higher education. Caste, class, religion, region or gender, determines the choice of courses and disciplines of students, which later influence their life chances and socio-economic mobility (Velaskar, 1990; Apple, 2001; Fuller, 2011; Tilak, 2013).

The popular discourses which surround professional education (as a component of higher education) state that it is attended by middle and higher class people. The professional practice is based on specialised knowledge, and acquiring it takes time, effort, and formal instruction, especially university-based training. The distinctive roles and specialized skills of professionals provide them with considerable power. Max Weber saw professionals as occupational groups which control access to scarce and highly marketable skills and are situated in the middle and upper levels in stratified societies; a major characteristic of professionals being relative superiority over and distance from the working classes. M. Weber argues that particular credentials determine the social status of an individual (Weber, 1946). UNESCO (1990) considers that technical education is a formal education designed to provide knowledge and skills underlying production processes with a wider connotation than vocational education at a secondary or higher level. Technical education mainly aims at preparing students for occupations that are classed above the skilled crafts but below the scientific or engineering professions. It emphasizes the understanding and practical application of basic principles of science and mathematics, rather than the attainment of proficiency in manual skills that are properly the concern of vocational education (www.britannica.com/topic/technical-education).

Mark Kirby (1999) and Sally Tomlinson (2017) argue that the larger discourses surrounded by professional education and technical education suggest that they are attended by the middle-class and upper-class children and thereby reproduce the elite structure of society. Even P. Bourdieu (2016) views that higher education and professional education, which are considered as a passport to prestigious occupations, are virtually monopoly of selected people with particular accumulated capital. P. Bourdieu $(1984,1996,2016)$ argues that certificates and diplomas are the tacit criteria set by the ruling class to identify people from a particular social origin. Educational inequalities are just a transformation of social inequalities and a way of reproduction of the social status quo. J. Tilak (2013) argues that more attention has been given to the market relevant areas of study and less to standard or traditional areas of study like liberal arts, humanities, and sciences. He also discusses the development of elite and non-elite or mass institutions. The latter is largely characterized by poor quality and huge enrolment. In India, the majority of masses are absorbed in non-elite academic institutions. Hence, it is important to know who has the privilege of attaining different types of higher education at an empirical level and what are the background characteristics of those individuals who are attaining higher education in India. 


\section{BACKGROUND}

After gaining independence, higher education in India has increased exponentially not only to build new socio-economic order but also to establish political legitimacy. However, such expansion has not taken into consideration the issue of quality and equality, and the problems associated with higher education multiplied. Inequality among the social groups with regard to access to quality education is one of the biggest issues which the system of Indian higher education is facing (Velasker, 1990). The access to education among various social groups such as Scheduled Castes (those castes which suffered from extreme social, educational and economic backwardness arising out of the age-old practice of untouchability in India see: https:/ / www.britannica.com/ topic/Scheduled-Caste), Scheduled Tribes (those groups of people which are identified by the government of India under different provisions of the Constitution as tribes, see: https://indiantribalheritage.org/?p=21438), women, religious minorities produces a dismally poor picture. In India, the subject of educational inequalities holds enormous social significance, given the traditional inequalities where certain groups are considered unfit for knowledge (Patgania \& Tierney, 2018). Today, vast expansion in enrolment has occurred but educational inequality between privileged and unprivileged continues to persist in new forms. The particular socio-economic backgrounds of individuals provide them with particular capital which determines the educational choices and success of an individual. Although the above-mentioned socially disadvantaged groups have gained access to higher education, the kind of education they acquire requires scrutiny.

India's higher education system is the world's third-largest in terms of students, next to China and the United States. The current expansion of education in India has been predominantly privately-financed. As per All India Survey on Higher Education (AISHE) 2017-18, the Gross Enrolment Ratio (GER) in higher education has increased from $24.5 \%$ in $2015-16$ to $25.8 \%$ in 2017-18 (https:// pib.gov.in/Pressreleaseshare.aspx?PRID=1541358). "Total enrolment in higher education has been estimated to be 34.6 million with 18.6 million boys and 16 million girls. Girls constitute $46.2 \%$ of the total enrolment. Gross Enrolment Ratio (GER) in Higher education in India is $24.5 \%$, which is calculated for 18-23 years of age group. GER for the male population is $25.4 \%$ and for females, it is $23.5 \%$. For Scheduled Castes, it is $19.9 \%$ and for Scheduled Tribes, it is $14.2 \%$ as compared to the national GER of 24.5\%(https://mhrd.gov.in/sites/upload_files/mhrd/files/statistics-new/ AISHE2015-16.pdf)".

According to the Government of India (2016), about 79.3\% of the students are enrolled in undergraduate level programmes and 126,451 students are enrolled in doctorate studies, that is, less than $0.4 \%$ of the total student enrolment. At the undergraduate level, the highest number of students is enrolled in arts/humanities/social sciences courses followed by science, engineering and technology, and commerce. At the doctorate level, maximum students 
are enrolled in the science stream, followed by engineering and technology. On the other hand, at post-graduate level maximum students are enrolled in the social science stream; management comes at number two. In Jammu and Kashmir, total enrolment in higher education is 332,556 and out of this male enrolment is 162,548, and female enrolment is 170,008. The total enrolment for Muslims in Jammu and Kashmir is 127,825 and out of this, male and female enrolment is 67,932 and 59,893 respectively and the total percentage of the Muslim population in Jammu and Kashmir is $67 \%$. Thus the overall enrolment of Muslims in higher education in Jammu and Kashmir is much lesser than other groups.

On August 5,, 2019, the central government divided the state of Jammu and Kashmir into two Union Territories (UTs) namely UT of Jammu and Kashmir, and UT of Ladakh. Srinagar is situated in the UT of Jammu and Kashmir and is the summer capital of the erstwhile state of Jammu and Kashmir. Jammu and Kashmir (J\&K) is situated in the northernmost part of India with a total population of 12.5 million. Jammu and Kashmir is not well developed industrially. The total number of females per thousand male population (also known as sex ratio) in the state is 883 . Srinagar is the summer capital and second -most-populous district of Jammu and Kashmir. The total literacy rate of Jammu and Kashmir is $68.74 \%$. The total male and female literacy rate is $78.26 \%$ and $58.01 \%$ respectively. The literacy rate of Srinagar district is $60.52 \%$ out of which $66.31 \%$ of males are literate and $54.1 \%$ of females are literate (Census, 2011). As of November 2010, Srinagar district has two universities, six-degree colleges, one Bachelor of Education (B.Ed) college, one National Institute of information technology (NIIT), two polytechnics, and three Industrial Training Institutes (ITI) (NSDC, 2013). In Srinagar, 13\% of the total workers are engaged in agriculture and the rest are engaged in non-agricultural activities (Government of Jammu and Kashmir, 2015).

\section{OBJECTIVES}

The macro-level databases such as the census and National Sample Survey Office (NSSO) provide information about the prevalence of higher education among various social groups. These databases are unable to provide nuanced information on the socio-economic and demographic background of students and the association of these with the subjects enrolled (Robinson, Raja, Choudhury, \& Saikia, 2016). This study tries to overcome this limitation of the macro-level databases and examines the background characteristics of the respondents and describes the choices and selections of different courses of higher education in the context of the social backgrounds of the respondents. We have divided higher education into three sub-categories: professional education, technical education, and graduate and above, excluding professional and technical courses GP (EPTC). 


\section{METHODOLOGY}

It was a community-level study. It was conducted in Nalabal, Alamgari Bazar, and Baghi Ali Mardan Khan areas of district Srinagar of Jammu and Kashmir (India). Purposive sampling was used to select these areas. The criterion of selection of the areas was occupational and educational heterogeneity of the people living in the areas. The respondents awee included in the study by applying the census method (Perecman \& Curran, 2006). The unit of study (respondent) was anybody who is part of the labour force, excluding students who were enrolled in some educational institution and persons who were below 15 years and above 65 years old. This study covered 245 households from the above-mentioned areas consisting of 704 respondents. A survey method was used to collect information from the respondents. Structured interviews were conducted by making use of interview-schedules and primary data was collected from all 704 eligible respondents. The interview-schedule is a list of questions, which are asked by the researcher, and the answers given by the respondents are documented (Blaikie, 2000). Our interview-schedule contained forty questions related to the demographic, socio-cultural, and economic background of the respondents and other specific questions related to the research. One of the authors (the research scholar) herself met the respondents and collected information in the local language. The primary data is organized in the form of cross-tables using SPSS and analysed in the form of descriptive statistics.

\section{FINDINGS}

\section{Prevalence of Higher Education}

In order to explore educational attainment of respondents, we have categorized educational attainment of the respondents into five categories: (i) illiterate; (ii) primary to senior secondary; (iii) professional education; (iv) technical education; and (v) graduate and above (excluding professional and technical courses) or GA (EPTC). It is important to mention here that in this study, higher education includes professional education, technical education, and GA (EPTC). The findings reveal that of the total respondents ( $\mathrm{N}=704), 9.4 \%$ are illiterate, $42.2 \%$ have academic qualifications varying between primary to senior secondary, $1.7 \%$ havetechnical education, $14.5 \%$ have professional education and $32.2 \%$ are GA (EPTC). Thus the prevalence of higher education (sum of technical education, professional education, and GA(EPTC)) in the research sample is $48.4 \%$. This percentage gives the impression that the prevalence of higher education is very substantial in the research sample. However, higher education as such is not a homogeneous or monolithic category. The empirical findings show that this higher education is highly stratified with different groups of people choosing different streams not freely but on the basis of structural and cultural conditions and conditionings. In this paper, we examine the higher education prevailing among this $48.4 \%$ of the total respondents. 


\section{Professional education}

In the present study, professional education is categorized into: (i) engineering; (ii) medical; (iii) law; (iv) management/social work; (v) journalism; and (iv) Bachelor of Education/Master of Education (B.Ed/M.Ed). The total proportion of professional education among the respondents in the study sample is low. It is found that of the total respondents who have professional education $(\mathrm{N}=102), 24.5 \%$ have completed their courses of engineering, $14.7 \%$ have completed their courses of medical, $4.9 \%$ of law, $29.4 \%$ of management/social work, $2.0 \%$ of journalism and $24.5 \%$ of B.Ed/M.Ed. Thus, eighty per cent of respondents have completed their professional education from courses like the management/social work, engineering, and B.Ed/M.Ed. Professional courses such as journalism and law are not very popular among the respondents in the study sample.

\section{TECHNICAL EDUCATION}

In this study, technical education includes the following categories: (i) related to engineering and computers; (ii) related to agriculture; (iii) related to nursing and lab technician; and (iv) related to hotel and hospitality. It is observed that of the total respondents $(\mathrm{N}=704)$, only $1.7 \%$ have any technical education. Thus, the prevalence of technical education in the study sample is very low mainly because of the absence of any large scale industrialisation in Srinagar city. These respondents have largely completed their technical education from courses related to computers and engineering and nursing and lab technician. Technical education related to agriculture, hotel, and hospitability is not very popular among the respondents.

Graduate and Above (Excluding Professional and Technical Courses) or GA (EPTC)

In the present study, GA (EPTC) includes following five categories: (i) Only graduate (Bachelor degrees); (ii) Master of Arts (M.A); (iii) Master of Science (M.Sc.); (iv) Masters of Commerce (M.Com.); and (v) PhD/M.Phil. It is observed that of the total respondents who are GA (EPTC) (N=227), 58.6\% are only graduate (bachelors), 37.5\% have done post-graduate (masters); out of this 37.5\%, 20.7\% have done M.A, only $8.4 \%$ have done M.Sc., and again $8.4 \%$ have done M.Com. Thus, a small proportion of respondents has completed their post-graduation studies in science and commerce. Further, only $4.0 \%$ have done Ph.D./M.Phil. Thus within GA (EPTC) more than half of the respondents are only graduates. Hence, it is observed that of the total respondents, the majority have completed their courses from GA (EPTC). 


\section{BACKGROUND CHARACTERISTICS AFFECTING HIGHER EDUCATION}

\section{Gender}

The presence of women is low in professional courses such as engineering and medical professions. It is noted that out of the total female respondents who have any professional education, only $9.4 \%$ have completed their professional courses in engineering, and $7.5 \%$ have completed their professional courses in medical. Among all the men who have completed professional training, $40.8 \%$ are engineers. Besides, among all the engineers, almost $80 \%$ are males. There is an under-achievement of females in such scientific subjects. This gender-sensitive choice of subject is important because courses like engineering and medical are considered very prestigious and employment-oriented but females have a low presence in them. However, women do have a significant presence in courses like management/social work, law, etc. In comparison to men, the prevalence of professional education is higher among women (52\%) because of the overwhelming presence of women in B.Ed/M. Ed courses. Within professional education, $45.3 \%$ of women opted courses like B.Ed./ M.Ed., which constitutes $96 \%$ of the total respondents who have done B.Ed./M.Ed. Within technical education, the proportion of males is higher than females. Males largely completed their technical education from courses related to engineering and computers, whereas females completed their technical education from courses related to nursing and lab technician. Among the total male respondents who are GA (EPTC), $64.0 \%$ are only graduates, $11.7 \%$ have done M.Com, 10.8\% have done M.A, 9.9\% have done M.Sc., and 3.6\% have done PhD/M.Phil. Similarly, of the total females who are GA (EPTC), 53.4\% are only graduates, $30.2 \%$ have M.A, $6.9 \%$ have M.Sc., $5.2 \%$ have M.Com. and $4.3 \%$ have done Ph.D./M.Phil. Thus, there is a tendency among the girls to choose softer and more feminine options. Both home and school processes are at work in the causation of this stereotype results.

Age

It is observed that of the total respondents who have any professional education, about half of the youth (15-30 years) (both males and females) have completed their professional degree in the courses like the management/ social work whereas respondents who belong from the age group of 30-45 years, half of them have completed their professional degree in the courses like medical and engineering. The proportion of youth in courses like engineering and medical is lower as compared to the respondents of other age groups. It shows that the younger generation is attracted to new professional courses like management and social-work etc., which are more market-relevant and find placements in newly emerging private or corporate sectors. In all age groups, the proportion of women in professional courses like engineering and medical is lower. Technical education is more prevalent among the respondents who belong to the age group of $30-45$ years and is not popular among the youth. 
We find that preference for conventional master degree is higher among the older generation belonging to the age group 45 years to 60 years (about $55 \%$ ). But among the younger (15-30 years) and middle age (30-45 years) groups, preference for conventional master's degree has declined. Further, the younger generation has developed a preference for M.Com. as compared to the older generations.

\section{Father's education}

A significant factor that influences academic success as pointed out by P. Bourdieu (1993) is the "domestic transmission of cultural capital" which is a process that economists have always neglected. Economists have only taken monetary investments into account and are unaware that cultural capital transmitted within families is an important resource which strengthens individuals with knowledge, practical adeptness, and an understanding of the way things work (the rule of the game), thus enhancing their educational attainment and success. Parent's educational credential serves as cultural capital for their children and provides advantages to them. Individuals who are second-generation learners have often better cultural capital than those who are first-generation learners.

It is observed that respondents who have any professional qualifications and whose father is illiterate, mostly did their professional training in management/social work and B.Ed./M.Ed. Among the respondents who have any professional qualifications and whose father also has some professional training, 37\% have completed their professional courses from engineering; similarly, respondents whose father is GA (EPTC) have mostly completed their professional training in engineering. Technical education's prevalence is more among respondents whose father has educational qualifications up-to senior secondary. We observe that among the respondents who are GA (EPTC) and whose father is illiterate, more than $60 \%$ are only graduates. Among the respondents who are GA (EPTC) and whose father has educational qualifications up-to senior secondary, half of them are only graduates and more than $43 \%$ have done post-graduation. Similarly, among the respondents who are GA (EPTC) and whose father is also GA (EPTC), $61 \%$ are only graduates, $21.7 \%$ have done any post-graduation and $17.4 \%$ have done Ph.D./M.Phil. Further, among the respondents whose father has some professional qualifications, a very small proportion of respondents are seen within the educational category of GA (EPTC) as these people largely have completed their higher education in some professional courses.

\section{Father's occupation}

The economic position of the father also impacts the educational attainment of an individual. It is observed that respondents of higher social class origins are more likely to aspire for higher education than respondents of lower social class origins. However, mere investment in education does not bring equality in educational attainment and opportunities as different social classes have a 
differential chance of profit out of economic and cultural investments. Investment in education is in itself an effect of the domestic transmission of cultural capital. Particular social class possesses particular cultural and social capital; the former instils indirectly and in a subtle way where parental expectations and value orientations play a role, while the latter helps in developing necessary social contacts.

Among the respondents who have any professional education and whose father is in government service, $36.2 \%$ have completed their professional courses in engineering, whereas among respondents whose father is in private service, nearly $12.8 \%$ have completed their professional courses in engineering. Thus, respondents who have done engineering and medical courses are largely those whose father is in the government sector. Similarly, among the respondents who have any professional training and whose father is self-employed, more than a half have completed their professional courses in management/social work and B.Ed./M.Ed. Similarly, respondents who have any professional education and whose father is working as a daily wage worker are more likely to attend courses such as B.Ed./M.Ed. The respondents who have completed technical education are those whose father is working either in government service or self-employment. Most of the respondents who have completed GA (EPTC) are those whose father is self-employed. Highest educational degrees like $\mathrm{MS} / \mathrm{PhD}$ are obtained by those whose father is either in self-employment or in government service and a similar pattern is seen even among those who have done M.Sc., M.Com, or M.A degrees. Very few respondents whose father is in private service or daily wage workers have obtained this type of education.

\section{Caste}

The existence of the caste system among the Muslims in India has been an object of analysis for a long time and has raised debates among scholars. In Kashmir, certain studies on caste have divided caste into four categories, where they placed Sayyids at the top, followed by Mughals, Pathans, and Taifadarans (Lawrence, 1891; Sinha, 2003). There are debates regarding the prevalence of caste among the Muslims, and this debate often arises because caste conventionally is seen in continuity with Varna and the four-fold birth-based hierarchy prevailing within it. However, scholars like Imtiaz Ahmed (1978), Seik Rahim Mondal (2003), and Sayyed Zainuddin (2003) confirm that there exist caste-like features among Muslims. Patgania and Tierney (2018) argue that in modern society, caste continues to shape inequality though not in the same traditional way but in more hidden and different forms, where particular caste uses its caste capital to influence the distribution process.

This study has also found the presence of caste and caste-like groups because of the conventional association of people with specific occupations and networking of social and cultural capital. In this study, we have classified the castes and caste-like groups into three groups, namely; Group-I, Group-II, and Group-III. Group-I and II are caste-like groups, and Group-III is a caste group; hierarchy is very visible among these three groups. Group-I is at the 
top of the hierarchy and Group-III is at the bottom. Group-III exhibits all the features of a caste group.

We observed that regarding the respondents from Group-I, Group-II, and Group-III, the total prevalence of professional education is $24.5 \%, 22.4 \%$, and $11.8 \%$, respectively. When explored further, it is observed that $46.2 \%$ of the respondents from Group-I have completed their professional course in engineering and $30.8 \%$ have completed their professional course in management/social work, whereas more than half of the respondents from Group-III have completed their professional courses from management/social work and B.Ed/ M.Ed. The representation of Group-III respondents in engineering and medical is much lower than in Group-I respondents. Education is often viewed as a path towards bringing social change and equality of opportunities. However, these claims of education are rejected by Velaskar (1990), Amman Madan (2013), and Zoya Hasan (2016), as they state that education in India is marked by sharp disparity and it often reproduces structures of inequalities. Our findings also support these arguments, where the representation of the dominant strata of society is disproportionately higher in the elite courses. When explored further, $57 \%$ of males from Group-I have completed their professional courses in engineering, whereas $46.7 \%$ males from Group-II have completed professional courses inengineering, and $33.3 \%$ males from Group-III have completed their professional courses in management/social work and $33.3 \%$ in engineering. Females from Group-I largely have completed professional courses of engineering (33.3\%) and B.Ed./M.Ed. (33.3\%). Among Group-II and III respondents, a very small proportion of females has completed their professional courses in engineering and medical field. These females can be seen more in courses such as B.Ed./M.Ed. and management/ social work. In terms of caste and caste-like groups, technical education is more prevalent among Group-III respondents. Within the educational category of GA (EPTC), it is observed that of the total respondents who belong from Group-I, $46.7 \%$ are only graduates, $50 \%$ have done P.G, and $3.3 \%$ have done $\mathrm{PhD} / \mathrm{MPhil}$, whereas of the total respondents who belong to Group-III, $61.5 \%$ are only graduates, $34.1 \%$ are post-graduates, and $4.3 \%$ have done $\mathrm{PhD} / \mathrm{MPhil}$. Further, Group-III respondents are seen more in conventional courses like arts, humanities, and sciences.

\section{DISCUSSION}

Bringing social equity and justice into formal education is one of the cherished and prolonged goals of India since India has achieved independence and the expansion of higher education is seen as a policy intervention to curb social and income inequality. However, the strategies of democratization and compensatory discrimination to ensure equal distribution of educational facilities remain unfulfilled not only because of conflict of interest between groups but also due to institutional incapacities. It is observed that the distribution of 
educational opportunities has followed emergent patterns of social differentiation and social inequalities. This pattern represents the complex interaction and interweaving of traditional and newly-evolving structures of caste, class, patriarchy, religion, etc. Educational facilities are unequally distributed among the various socio-economic groups, which has created inequality in educational opportunities and attainments.

Over the period, women's access to education has increased and their overall enrolment in higher education has also increased. It is often claimed that gender inequality within higher education has decreased significantly; nonetheless, there is under-achievement of females in technical and scientific subjects. Women tend to concentrate on those disciplines which are usually identified as feminine and commanding weak rewards in terms of wage, authority, and social prestige. Besides gender, socio-economic and cultural backgrounds of an individual often determine his/her choice of choosing subjects, which later determines their life chances and socio-economic mobility. Parent's education endows their children with better choices of courses and institutions. Gaining and equipping oneself with cultural capital can lead to academic success and upward mobility in the social ladder. It is observed that respondents who have lower educational credentials are largely those whose parents are either illiterate or have some lower qualifications. Individuals whose parents are well qualified, their proportion in technical and scientific academic programmes is disproportionately high. When individuals whose parents are well-qualified join the so-called elite courses, they find it easy to assimilate because they have cultural capital (accumulated through parents) that the institution seeks and rewards.

The occupation of a father impacts educational attainment within higher education. It is observed that, in higher education, the proportion of the respondents whose father is in government service or is self-employed is higher. However, it is observed that children of persons having reputed government services are more likely to aspire for technical and scientific areas of study, especially those which are more market-relevant, whereas children whose father is self-employed are largely enrolled in non-professional and non-technical courses, especially in more conventional courses such as liberal arts, humanities and sciences. Payment of educational charges or fee is not the only factor which makes the occupation of parents or their class an important factor, as particular social class possesses particular cultural and social capital and these instil indirect and more subtle parental expectations, value orientations and social contacts. Further, the father's occupation is often seen as an indicator of the family's access to cultural capital in its embodied as well as objectified states.

Education is a sophisticated arena, in which caste and other forms of discrimination are often hidden. In order to compete for secular resources, traditionally dominating caste uses its caste capital (which exists in the form of social, cultural and economic capital) to influence the distribution process in such a way that everything appears natural or a class-based com- 
petition. The proportion of traditionally dominating caste group is higher in higher education, especially in professional education. The lower castes often lack social, economic and cultural capital and thus continue to remain deprived of education. It is observed that with increasing educational level, the proportion of lower caste decreases. Moreover, their representation in a so-called elite courses is disproportionately lower. Thus, caste and caste-like groups are operating in a disguised form, producing inequalities in educational opportunities and educational attainment and maintaining those inequalities through various caste institutions. Thus the socio-cultural position of an individual provides them with particular capital accumulated through generations.

From the foregoing discussion, it can be concluded that large sections of the population are gaining entry into higher education system but such expansion does not necessarily contribute in achieving the egalitarian goals of 'education for all'. It has also been argued by Bourdieu (1993) and Bourdieu and Passeron (1977) that educational inequalities are just transformation of social inequalities and a way of reproduction of the status quo. Higher education has not been able to transform traditionally entrenched structures of inequality. Higher education conserves the privileges of the privileged because the background characteristics which are examined in this paper show the dominance of ascribed values and social inheritance of the students as the features responsible for the attainment of higher education. The inequality in educational attainment and educational opportunity is not simply the outcome of improper allocation of capital, inadequate educational planning, lack of adequate teachers or infrastructure, etc. The problem of educational inequality is rooted in the structure of unequal distribution of the overall resources like political power, wealth and social status and other resources in a given society. The present organisation of the educational system is conditioned by the historical, political, economic and cultural context of society. There is a need to promote structural changes for eliminating inequality in education where, besides acknowledging the instrumental role of education, education should be viewed as a vehicle towards liberation, cultural realisation as well as social transformation.

Thus, we see that higher education is getting increasingly differentiated in India. There are professional, technical and non-professional courses, which are dominating the sphere of higher education. Within each of these categories, several streams and courses have developed. The choice for such courses depends on the interplay of several background characteristics including age, gender, father's education, father's occupation and caste of the students. These background characteristics help in connecting and carrying forward the privileges as well as constraints of one generation to another. We can conclude this paper stating that although higher education is witnessing expansion in India, it is yet to come above the traditional bondages of structural and family-based factors. 


\section{REFERENCES}

[1] Ahmed, I. (1978). Caste social stratification among Muslims in India. New Delhi: Manohar Publications.

[2] All Indian survey on higher education (AISHA). Retrieved January 23, 2020, from https://mhrd. gov.in/sites/upload_files/mhrd/files/statistics-new/AISHE2015-16.pdf.

[3] Apple, M. W. (2001). Comparing neo-liberal projects and inequality in education. Comp Educ, 37(4), 409-423.

[4] Bourdieu, P., \& Passeron, J. C. (1977). Reproduction in Education, Society and Sulture. Beverly Hills, CA: Sage.

[5] Bourdieu, P. (1984). Distinction: A Social Critique of the Judgment of Taste. London: Routledge.

[6] Bourdieu, P. (Ed.). (1993). The Field of Cultural Reproduction: Essay on Art and Literature. UK: Columbia University Press.

[7] Bourdieu, P. (1996). The State Nobility: Elite School in the Field of Power. Clough. U.K: Polity Press.

[8] Bourdieu, P. (2016). The forms of capital. In: A. R. Sadovnik \& R. W. Coughlan (Eds.), Sociology of Education: A Critical Reader (pp. 83-95). New York: Routledge.

[9] Blaikie, N. (2000). Designing Social Research: The Logic of Anticipation. USA: Blackwell Publishers.

[10] Census. (2011). Office of the Registrar General \& Census Commissioner, India Ministry of Human Affairs, Government of India.

[11] Coleman, J. S. (1988). Social capital in the creation of human capital. American Journal of Socio$\log y, 94-120$.

[12] Encyclopaedia Britannica. Retrieved February 26, 2020, from www.britannica.com/topic/ technical-education.

[13] Encyclopaedia Britannica Retrieved March 11, 2020, from https://www.britannica.com/topic/ Scheduled-Caste.

[14] Fuller, C. (2011). Sociology, Gender and Educational Aspiration. London: Continuum. (2016). All India survey on higher education (2015-16), Ministry of Human Resource Development (MHRD), New Delhi: Government of India. (2015). JEK economic survey (2014-15) Volume-I, Directorate of Economics \& Statistics, Jammu and Kashmir: Government of Jammu and Kashmir.

[15] Graham, G. (2013). The university: A critical comparison of three ideal types. In: R. Sugden, M. Valania \& J. R.Wilson (Eds.), Leadership and Cooperation in Academia Reflecting on the Roles and Responsibilities of University Faculty and Management (pp. 1-5). UK: Edward Elgar Publishing Limited.

[16] Gumport, P. J. (2007). Sociology of Higher Education: Contribution and Contexts. US: The Johns Hopkin University Press.

[17] Hasan, Z. (2016). Disparities in access to higher education. In: A. K. Singh (Ed.), Education and Empowerment in India (pp. 128-137). New Delhi: Routledge.

[18] Hasley, A. H. (2006). The European university. In: H. Launder, P. Brown, J. A. Dillabough \& A. H. Hasley, (Eds.), Education, Globalization, and Social Change (pp. 854-865). New York: Oxford Press.

[19] Kariwo, M., Gounko, T., \& Nungu, M. (2014). Comparative Analysis of Higher Education. Canada: Sense Publishers.

[20] Kirby, M. (1999). Stratification and Difference. London: Macmillan.

[21] Kromydas, T. (2017). Rethinking higher education and its relationship with social inequalities: past knowledge, present state and future potential. Palgrave Communications, 3(1), DOI: 10.1057/s41599-017-0001-8.

[22] Lawrence, R. (1891). The Valley of Kashmir. London: Oxford University Press.

[23] Madan, A. (2013). Does education really change society: Theoretical reflection on a case study. In: G. B. Nambissan \& S. Rao (Eds.), Sociology of Education: Changing Contours and Emerging Concern (pp. 136-153). New Delhi: Oxford.

[24] Mondal, S. R. (2003). Social structure, OBCs and Muslims. Economic and Political Weekly, 38(46), 4892-4897.

[25] NSDC. (2013). National skill development corporation. District Wise Skill Gap in Jammu E Kashmir.

[26] Patgania, G. J., \& Tierney, W. G. (2018). An ethnography of caste and class at an Indian university: creating capital. Tertiary Education and Management, DOI: 10.1080/13583883.2018.1439998. 
[27] Perecman, E., \& Curran, S. R. (2006). A Handbook for Social Science Field Work: Essays and Bibliographic Sources on Research Design and Methods. California: Sage.

[28] Press Information Bureau Government of Indian Ministry of Human Resource Development. Retrieved February 26, 2020, from https:// pib.gov.in/Pressreleaseshare.aspx?PRID=1541358.

[29] Robinson, R., Raja, W., Choudhury, H., \& Saikia, D. J. (2016). Sociology of education and Indian higher education systems: A university's institutional research model. Economic $\mathcal{E}$ Political Weekly, II (9), 67-73.

[30] Saito, M. (2003). Amartya Sen's capability approach: A critical exploration. Journal of Philosophy of Education. 37(1). 17-33.

[31] Sen, A. (1971). The crisis in Indian education. In: S. C. Malik (Ed.), Management and Organisation of Indian Universities (pp, 248-278). Simla: Indian Institute of Advanced Study.

[32] Sen, A. (1985). Commodities and capabilities. Amsterdam, North Holland: Oxford University Press.

[33] Sen, A. (1993). Capability and well-being. In: M. Nussbaum, \& A. Sen (Eds.), The Quality of Life (pp. 30-50). Clarendon Press: Oxford.

[34] Sen, A. (2000). Development as Freedom. New Delhi: Oxford.

[35] Sinha, S. C (2003). JEK Anthropological Survey of India. New Delhi: Monohara Publication.

[36] Tilak, J. (2013). Higher education in the BRIC member-countries: comparative patterns and policies. Economic \& Political Weekly, xlviii(14), 41-47.

[37] Tomlinson, S. (2017). A Sociology of Special and Inclusive Education: Exploring the Manufacture of Inability. New York: Routledge.

[38] UNESCO. (1990). Trends and Development of Technical and Vocational Education, France: United Nations, Educational, Scientific and Cultural Organization.

[39] Velaskar, P. (1990). Unequal schooling as a factor in the reproduction of inequality in India. Sociological Bulletin, 39(1-2), 131-45.

[40] Walker, M., \& Unterhalter, E. (2007). Amartya Sen's Capability Approach and Social Justice in Education. US: Palgrave.

[41] Weber, M. (1946). Class, status, party. In: H. H. Gerth and C. W. Mill (Eds.), From Weber: Essays in Sociology (pp. 180-195). New York: Oxford.

[42] Who are Scheduled Tribes?: Clarifications by the National Commission for Scheduled Tribes - Government of India. Retrieved February 18, 2020 from https://indiantribalheritage.org/?p=21438.

[43] Zainuddin, S. (2003). Islam, social stratification and empowerment of Muslims OBCs. Economic and Political Weekly, 38(56), 4898-4901. 